\title{
Durum wheat quality I: some physical and chemical characteristics of Syrian durum wheat genotypes
}

\section{El-Khayat, GH}

http://hdl.handle.net/10026.1/1437

\author{
10.1111/j.1365-2621.2006.01245.x \\ International Journal of Food Science and Technology \\ Wiley
}

All content in PEARL is protected by copyright law. Author manuscripts are made available in accordance with publisher policies. Please cite only the published version using the details provided on the item record or document. In the absence of an open licence (e.g. Creative Commons), permissions for further reuse of content should be sought from the publisher or author. 


\title{
Original article
}

\section{Durum wheat quality I: some physical and chemical characteristics of Syrian durum wheat genotypes}

\author{
Ghassan H. El-Khayat, ${ }^{1,2}$ Jihad Samaan, ${ }^{1}$ Frank A. Manthey, ${ }^{3}$ Mick P. Fuller ${ }^{1}$ \& Charles S. Brennan ${ }^{1,4 *}$ \\ 1 School of Biological Sciences, University of Plymouth, Plymouth, PL4 8AA, UK \\ 2 Food Science Department, Faculty of Agriculture, University of Damascus, Damascus, Syria \\ 3 Department of Plant Sciences, North Dakota State University, Fargo, ND, USA \\ 4 Institute of Food Nutrition and Health, Massey University, Private Bag 1222, Palmerston North, New Zealand
}

(Received 17 August 2005; Accepted in revised form 10 November 2005)

Summary Some physical and chemical characteristics of nine Syrian durum wheat genotypes were determined in order to investigate the relationships among individual kernel components and kernel quality. All genotypes were grown on fully irrigated plots in Syria. Test weight, 1000-kernel weight, kernel size distribution, hardness and semolina extraction rates were determined along with the chemical characteristics of the kernel (ash, moisture, protein, wet gluten, starch content and falling number). All tested genotypes had high test weight $\left(83.1-85.9 \mathrm{~kg} \mathrm{hl}^{-1}\right)$ and 1000 -kernel weight $(42.5-55.5 \mathrm{~g})$ indicating high milling yield potential. Additionally, all the wheat genotypes demonstrated high falling numbers (433-597 s). Correlation coefficients among the quality properties showed that moisture content did not demonstrate any strong correlations with the studied quality parameters. Protein content exhibited a positive correlation with vitreousness $(r=0.78)$, and a negative correlation with ash content $(r=-0.57)$. Test weight exhibited a negative correlation with 1000kernel weight $(r=-0.66)$, and a positive correlation was observed between test weight and starch content of the kernel $(r=0.78)$. The results illustrate the commonality between Syrian durum wheat genotypes and US and Canadian durum wheat genotypes reported by researchers previously.

Keywords Durum wheat, gluten, protein content, starch, vitreousness.

\section{Introduction}

Durum wheat is an important cereal crop for Syria and countries around the Mediterranean. Pasta is regarded as the major end-product for which the majority of the crop is grown; hence, the selection and use of cultivars possessing optimal processing characteristics is imperative for both the grower and food processor. The physico-chemical quality of the durum wheat kernel is the major determinant of the suitability of the crop for its end-use, and inevitably is responsible for the quality of pasta (Mariani et al., 1995). Factors which have been shown to affect durum wheat quality include genotype (Troccoli et al., 2000), environment (Kovacs et al., 1997; Sharma et al., 2002) and the interaction between genotype and environment.

The relationship between some of the physical characteristics (such as density, test weight, kernel size and kernel weight) and the chemical properties (such as

*Correspondent: Fax: +64 6350 5657;

e-mail: c.s.brennan@massey.ac.nz moisture, starch and protein content) have been studied extensively in Triticum aestivum (Igrejas et al., 2002a,b; Khatkar et al., 2002; Chung et al., 2003; Kim et al., 2003).

Early research by Tkachuk \& Kuzina (1979), studying hard red spring wheat, illustrated that an increase in grain moisture content caused a decrease in test weight and density, but an increase in kernel weight. Additionally, they demonstrated a negative correlation between test weight and protein content, possibly because of the association between shrunken grains and low test weight.

Another important factor that determines end-use quality characteristics of cereal is hardness. The hardness of a grain is important with regards to the milling process, where it has a significant impact on the facture characteristics of kernels during milling (Symes, 1961). This has a subsequent effect on factors such as, the conditioning of wheat before milling, the particle size of flour, quantity of damaged starch, water absorption, milling extraction rate (Hoseney, 1987; Pomeranz \& Williams, 1990; Delwiche, 1993), as well as the 
rheological properties of the flour produced (Pomeranz et al., 1984). Much of the research investigating the genetic basis of kernel hardness has been conducted on T. aestivum. Such work has illustrated the role of the starch granule proteins, sometimes named friabilins (Greenwell \& Schofield, 1986; Brennan et al., 1993) and other times puroindolines (Baldwin, 2001; Igrejas et al., 2001). The scarcity of these puroindolines in durum wheats is often regarded as one of the factors which explain the high hardness of durum wheat kernels.

In durum wheat, the degree of vitreousness of the kernel is often used, in conjunction with kernel hardness, to predict the quality of the cereal crop. The degree of kernel translucency, and hence the apparent degree of vitreousness, is related to the degree of compactness of the kernel (Yamazaki \& Donelson, 1983). The degree of vitreousness of kernels has been linked to the hardness of the kernel, and the amount of protein and starch within the kernel (Stenvert \& Kingswood, 1977). Starchy kernels have been shown to have a discontinuous endosperm with many air spaces and appear white in colour (Dexter et al., 1989). These air spaces, and the more porous nature of the kernel, appear to be related to softer texture of the starchy kernels. Many studies have shown that the environmental factors, such as, temperature and light intensity during grain development, determine whether the kernels will appear vitreous or starchy (Parish \& Halse, 1968; Hoseney, 1987). Pomeranz \& Williams (1990) observed that nitrogen fertilisation affects kernel protein content; and hence, the hardness and appearance of kernels. So the degree of vitreousness is highly influenced by both genetic and environmental factors.

Research by Matsuo \& Dexter (1980) illustrated that the degree of vitreousness has an important impact on the milling quality of durum wheat, because of its effect on semolina yield, granulation and protein content. Thus, when durum wheat is grown in low protein environments, a decrease in kernel protein content, an increase in starchiness (decrease of kernel vitreousness), and a decrease in semolina yield were observed. The reduction in semolina yield is possibly related to how quickly the starchy kernels were reduced to fine flour particles (Matsuo \& Dexter, 1980; Dexter \& Matsuo, 1981; Sissons et al., 2000).

Ash content is also regarded as a quality characteristic for durum wheat kernels as it has an influence on pasta colour. The faint colour of semolina is caused by high ash content, and may be due to high extraction rates (Cubadda, 1988). The resulting pasta tends to have a brown colour (Taha \& Sagi, 1987; Borrelli et al., 1999). Premium-grade semolina generally has ash content lower than $0.9 \%$ (Cubadda, 1988).

Protein content is one of the most important quality characteristic of durum wheat kernels in relation to determining pasta quality (Dexter \& Matsuo, 1977, 1980; Autran \& Galterio, 1989). As alluded to previously, protein content is highly influenced by environment much more than genotype (Mariani et al., 1995), where protein content increases with increasing temperature and reduced rainfall.

Dexter \& Matsuo (1977) investigated the influence of protein on some of durum wheat quality aspects for two Canadian durum wheat cultivars that differed in their protein contents, but were grown under the same environmental conditions. They found that the increase in protein content was associated with an increase in pigment content and improvement in cooking quality of resulted pasta. Although total protein content is a major factor in final pasta quality, research has also investigated the importance of the gluten components in determining the rheological and cooking quality of pasta (Damidaux et al., 1980; Du Cros et al., 1982; Carrillo et al., 1990).

Limited information is available concerning the quality of Syrian durum wheat. The aim of this study was to investigate some of the physico-chemical properties of durum wheat genotypes derived from a genetic pool in Syria, in the context of the Canadian and US durum wheat grading systems. To this end, nine Syrian durum wheat genotypes were grown at the same location under the same agricultural practices in order to determine the relationships among the physical and chemical characteristics of the kernels.

\section{Materials and methods}

Nine spring durum wheat genotypes (Sham-1, Sham-3, Sham-5, Bohouth-5, Bohouth-7, Douma-1105, Douma18861, Douma-26827 and Douma-29019) were selected for analysis. The first five genotypes are commercially available, whereas the Douma genotypes are experimental lines in the process of accreditation. The samples were obtained from Ministry of Agriculture Research Station at Raqqa (Northeast) of Syria, which is one of the main durum wheat provinces in Syria. All genotypes were grown at the same location and under the same agroecological conditions in the crop year 2002. The crops were from an irrigated agricultural practice and were not exposed to drought conditions. The land was previously laid down to vegetable crop production and the initial soil fertility was nitrogen $18.4 \mathrm{ppm}$, phosphorous $12 \mathrm{ppm}$ and potassium $220 \mathrm{ppm}$. Total rainfall for the 2001-2002 season was $184 \mathrm{~mm}$ with 13 recorded days where the field temperatures reached below $0{ }^{\circ} \mathrm{C}$, and no days recorded where the temperature was above $30^{\circ} \mathrm{C}$. The field plots received $4500 \mathrm{~L} \mathrm{ha}^{-1}$ of water during the growing season with the total amount of nitrogen and phosphorous used during fertilising of 138 and $69 \mathrm{~kg} \mathrm{ha}^{-1}$ respectively. 


\section{Physical analyses}

The degree of vitreousness was determined by hand sorting kernels. Vitreous kernels (those completely free of starchy or speckled appearance) were separated from a $15 \mathrm{~g}$ kernel sample, and weighed. Vitreousness was calculated as a percentage of vitreous kernels $(\mathrm{w} / \mathrm{w})$ in the sample. Test weight was determined using the Approved AACC method 55-10 (AACC, 2000); results were reported in kilograms/hectolitre. 1000-Kernel weight was determined using an electronic seed counter, where the number of kernels in a $10 \mathrm{~g}$ clean wheat sample was determined. Results were adjusted to reflect the weight of 1000 kernels.

Kernel size distribution was determined according to the procedure described by Shuey (1960), which used a kernel sizer consisting of two sieves, Tyler No. 7 with $2.92 \mathrm{~mm}$ openings and Tyler No. 9 with $2.24 \mathrm{~mm}$ openings. A $100 \mathrm{~g}$ of clean wheat was placed on the top sieve Tyler No. 7 and was shaken for $3 \mathrm{~min}$. Kernels remaining on the top sieve were classified as large kernels, while kernels passing through the top sieve and remaining on the second one were classified as medium kernels. Kernels passing through the second sieve were classified as small. Each fraction weight was reported as percentage of large, medium or small kernels.

A Single-Kernel Characterisation System was determined using SKCS 4100 (Perten Instruments, Huddinge, Sweden), using a 300-kernel sample (conditioned to $11 \%$ moisture). The SKCS had previously been calibrated using hard wheat samples. Means and standard deviation for weight, diameter, hardness index and moisture were recorded.

\section{Chemical analyses}

A whole wheat sample of each genotype was ground to wholemeal using a laboratory mill (Micro Hammer mill C680; Glen, Creston, Stanmoor, UK) and the flour sieved through standard sieves 500 and $250 \mu \mathrm{m}$ to obtain semolina-like flour particle size of $250 \mu \mathrm{m}$ for subsequent determinations. All chemical analysis were conducted on this milled semolina-like wholemeal flour.

Moisture content of the wholemeal flour sample was determined by the Approved AACC method 44-15 (AACC, 2000). Protein analysis was conducted by the Dumas method (Leco model FB-428) and expressed using the conversion factor $(\mathrm{N} \times 5.7)$. Wet gluten was performed according to the Approved AACC methods 38-12 (AACC, 2000) using a glutomatic (Perten Instruments, Springfield, IL, USA). Falling number was determined using the Approved AACC method 56-81B (AACC, 2000). Ash content was determined using the Approved AACC method 08-01 (AACC, 2000) and expressed on a $14 \%$ moisture content. Total starch was conducted using the Megazyme starch assay kit (Megazyme International,
Wicklow, Ireland), which corresponds to Approved AACC method 76-13 (AACC, 2000).

\section{Semolina yield}

Semolina production was achieved by cleaning the kernels using a Carter-Day dockage tester (SimonCarter Company, Minneapolis, MN, USA) that was configured with a number 25 riddle, and two number 2 sieves. Kernels were then scoured using a cyclone grain cleaner (Foster Manufacturers, Chicago, IL, USA) and tempered to $17.5 \%$ moisture. Tempered kernels were milled into semolina using a Bühler experimental mill fitted with two Miag laboratory scale purifiers (BühlerMiag, Minneapolis, MN, USA). Semolina extraction was expressed on a total product basis.

\section{Statistical analyses}

All measurements are means of at least three determinations. Correlation coefficients were run between the different variables using Microsoft Excel. Analysis of variance (ANOVA), followed by Tukey Student's test (significance level $P<0.05$ ), were performed using Minitab 1332 software package (Minitab Inc., State College, PA, USA).

\section{Results and discussion}

\section{Physical properties}

The physical properties of durum kernels, which relate to milling performance and overall assessment of durum wheat quality, are presented in Table 1. As the agronomic conditions of the trial plots were as uniform as possible with regards to field plot experiments, the variation in traits is likely to be a result of the genotypic variation within the genotypes examined.

The test weight values of the samples in this study were high and showed no significant difference between the genotypes, although values ranged from $83.1 \mathrm{~kg} \mathrm{hl}^{-1}$ for Sham-3 to $85.9 \mathrm{~kg} \mathrm{hl}^{-1}$ for Douma-29019. All of the genotypes exhibited 1000-kernel weights suitable for high quality kernels. 1000-Kernel weight did vary with genotype from $42.5 \mathrm{~g}$ for Douma-26827 to $55.5 \mathrm{~g}$ for Sham-3 (Table 1). Kernel weight for Syrian durum wheat genotypes were similar to those reported for US irrigated durum which had an average 1000-kernel weight of 47.3 in 2002 and $52.5 \mathrm{~g}$ in 2003 (Anon., 2003).

Kernel Size Index (Table 1) as measured by the procedure of Shuey (1960) showed that the durum wheat kernels tested were relatively large (Size greater than $2.92 \mathrm{~mm}$; Size No. 7 sieve) with genotypes having over $85 \%$ of the kernels tested being greater than $2.92 \mathrm{~mm}$. The percentage of the medium kernels ranged from $4.3 \%$ for Sham-3 and Sham-5 to $12 \%$ for 
Table 1 Physical characteristics of grain from Syrian durum wheat genotypes ${ }^{\mathrm{a}, \mathrm{b}}$

\begin{tabular}{|c|c|c|c|c|c|c|c|c|c|c|}
\hline \multirow[b]{2}{*}{ Genotype } & \multirow[b]{2}{*}{ TWT $\left(\mathrm{kg} \mathrm{hl}^{-1}\right)$} & \multirow[b]{2}{*}{ KWT (g) } & \multicolumn{3}{|c|}{ Kernel Size Index } & \multirow{2}{*}{$\begin{array}{l}\text { Kernel mean } \\
\text { diameter* }(\mathrm{mm})\end{array}$} & \multirow{2}{*}{$\begin{array}{l}\text { Vitreousness } \\
(\%)\end{array}$} & \multirow[b]{2}{*}{ Hard Index } & \multirow[b]{2}{*}{ Hard Class } & \multirow{2}{*}{$\begin{array}{l}\text { Semolina } \\
\text { yield (\%) }\end{array}$} \\
\hline & & & $L \%$ & $\mathbf{M} \%$ & $\mathbf{S} \%$ & & & & & \\
\hline Sham-1 & $84.9^{\mathrm{a}}$ & $50.3^{\mathrm{a}}$ & $91.0^{\mathrm{a}}$ & $7.7^{\mathrm{a}, \mathrm{b}}$ & $1.3^{\mathrm{a}}$ & $3.1^{\mathrm{a}}$ & $71.3^{\mathrm{a}}$ & $89.1^{\mathrm{a}}$ & $\mathrm{H}$ & $64.2^{\mathrm{a}, \mathrm{b}}$ \\
\hline Sham-3 & $83.1^{\mathrm{a}}$ & $55.5^{\mathrm{a}}$ & $94.0^{\mathrm{a}}$ & $4.3^{\mathrm{c}}$ & $1.3^{\mathrm{a}}$ & $3.2^{\mathrm{a}}$ & $52.7^{\mathrm{b}}$ & $86.7^{\mathrm{a}}$ & $\mathrm{H}$ & $62.9^{\mathrm{b}}$ \\
\hline Sham-5 & $84.9^{\mathrm{a}}$ & $50.4^{\mathrm{a}}$ & $94.6^{\mathrm{a}}$ & $4.3^{c}$ & $1.0^{\mathrm{a}}$ & $3.2^{\mathrm{a}}$ & $60.4^{\mathrm{c}}$ & $95.7^{\mathrm{b}}$ & $\mathrm{EH}$ & $65.0^{\mathrm{a}}$ \\
\hline Bohouth-5 & $84.1^{\mathrm{a}}$ & $55.1^{\mathrm{a}}$ & $91.6^{\mathrm{a}}$ & $5.7^{\mathrm{a}, \mathrm{c}}$ & $2.6^{\mathrm{a}}$ & $3.1^{\mathrm{a}}$ & $63.1^{\mathrm{c}}$ & $94.3^{a, b}$ & $\mathrm{EH}$ & $65.5^{\mathrm{a}}$ \\
\hline Bohouth-7 & $85.5^{a}$ & $49.6^{\mathrm{a}}$ & $89.0^{\mathrm{a}}$ & $9.7^{\mathrm{b}}$ & $1.3^{\mathrm{a}}$ & $3.1^{\mathrm{a}}$ & $85.7^{d}$ & $100.9^{\mathrm{b}}$ & $\mathrm{EH}$ & $65.5^{\mathrm{a}}$ \\
\hline Douma-1105 & $84.2^{\mathrm{a}}$ & $50.7^{\mathrm{a}}$ & $91.3^{\mathrm{a}}$ & $7.0^{\mathrm{a}}$ & $1.6^{\mathrm{a}}$ & $3.1^{\mathrm{a}}$ & $63.3^{c}$ & $91.5^{\mathrm{a}, \mathrm{b}}$ & $\mathrm{EH}$ & $62.7^{\mathrm{b}}$ \\
\hline Douma-18861 & $83.7^{\mathrm{a}}$ & $50.8^{a}$ & $88.3^{\mathrm{a}}$ & $9.6^{\mathrm{b}}$ & $2.0^{\mathrm{a}}$ & $3.0^{\mathrm{a}}$ & $93.6^{\mathrm{e}}$ & $96.1^{\mathrm{b}}$ & $\mathrm{EH}$ & $64.7^{\mathrm{a}}$ \\
\hline Douma-26827 & $85.5^{\mathrm{a}}$ & $42.5^{\mathrm{b}}$ & $85.3^{\mathrm{a}}$ & $12.0^{\mathrm{d}}$ & $2.7^{\mathrm{a}}$ & $2.9^{\mathrm{a}}$ & $50.4^{\mathrm{b}}$ & $90.6^{a, b}$ & $\mathrm{EH}$ & $62.9^{\mathrm{b}}$ \\
\hline Douma-29019 & $85.9^{\mathrm{a}}$ & $50.4^{a}$ & $92.0^{\mathrm{a}}$ & $6.7^{\mathrm{a}}$ & $1.3^{\mathrm{a}}$ & $3.2^{\mathrm{a}}$ & $69.4^{\mathrm{a}}$ & $89.3^{a}$ & $\mathrm{H}$ & $64.0^{\mathrm{c}}$ \\
\hline
\end{tabular}

Mean values in the same column followed by a different letter are significantly different $(P<0.05)$. TWT, test weight; KWT, 1000-kernel weight; $L$, large kernel size; M, medium kernel size; S, small kernel size; Vitreousness, vitreous kernel content; Hard Index, Kernel hardness index from SKSC; Hard Class, Hardness Classification from SKSC ( $\mathrm{H}$, hard; EH, extra hard).

*Determined from Single-Kernel Characterisation System.

Douma-26827. Small kernels ranged between $1.0 \%$ and $2.7 \%$ amongst the genotypes. The mean kernel diameter, as determined by SKCS, ranged from 2.9 to $3.2 \mathrm{~mm}$. 1000-Kernel weight had a positive correlation with kernel diameter $(r=0.69)$ and Kernel Size Index (KSI) large kernel content $(r=0.74)$ (Table 2). The high percentage of the large kernels supports the observations of high 1000-kernel weight and test weight values, indicating that the kernels from the majority of the genotypes were plump, unbroken and sound, and would be suitable for high milling yields.

Significant variations in the degree of vitreousness and hardness were observed among genotypes (Table 1). Vitreousness ranged from $50.4 \%$ for Douma-26827 to 93.6\% for Douma-18861. Previous studies have also indicated a high degree of variation in vitreousness within and between cultivars of on Syrian durum wheats (Shehadeh et al., 1999; El-Khayat et al., 2003). Hardness index varied from 86.7 for Sham-3 to 100.9 for Bohouth-7. Sham-5, Bohouth-5, Bohouth-7, Douma1105, Douma-18861 and Douma-26827 were classified as extremely hard. Sham-5, Bohouth-7 and Douma18861 had a higher hardness index than did Sham-1, Sham-2 and Douma-29019.

Kernel hardness was correlated with falling number $(r=0.65)$ and the degree of vitreousness $(r=0.63)$ (Table 2). This observation is similar to that of Stenvert \& Kingswood (1977) who found that vitreous kernels were harder than starchy kernels. It is interesting to note that the correlation between protein content of the kernel and hardness was very poor in our experiments $(r=0.37)$. This is despite the fact that protein content was significantly correlated with kernel vitreousness in our genotypes.

Semolina yield varied with Syrian genotype (Table 1). Semolina yield ranged from $62.7 \%$ for Douma- 1105 to $65.5 \%$ for both Bohouth-5 and Bohouth-7. Test weight, kernel weight, kernel size, kernel hardness and kernel vitreousness have been used by millers to assess the suitability of durum wheat for milling into semolina. Semolina extraction was correlated with hardness $(r=$ $0.75)$ and vitreousness $(r=0.57)$ (Table 2). Test weight, 1000-kernel weight, and kernel size did not correlate with semolina yield. Other researchers have reported that these traits did correlate with milling yield (Matsuo \& Dexter, 1980; Marshall et al., 1986; Dexter et al., 1987; Halverson \& Zeleny, 1988). Most research has been conducted on durum wheat with lower test weight, 1000-kernel weight and kernel size than the wheat used in this study. Genotypes in this study all had relatively high test weight, 1000-kernel weight and kernel size. Thus the variation among these genotypes for these traits was not sufficiently large to establish a relationship.

It is of interest to compare the quality of the Syrian durum wheats in terms of both the Canadian and US grading systems, especially in relation to market export potential.

The Canadian Grain Commission (CGC) specification of durum wheat grades classifies durum wheat into three grades according to the degree of vitreousness; grade No. 1, grade No. 2 and grade No. 3, where the minimum of vitreous kernels required are $80 \%, 60 \%$ and $40 \%$ respectively (CGC, 2001). The US grading system operates a subclassification system for durum wheat. Thus, under the US grading system durum wheat with over $75 \%$ vitreous kernel content is classified as Hard Amber Durum; wheat with less than 75 but greater than $60 \%$ vitreous kernel content is classified as Amber Durum; and with wheat with less than 60\% vitreous kernel content is classified as Durum. The US system also operates a numerical grading system based on test weight and content of damaged kernels, foreign material, shrunken and broken kernels, and wheat of 


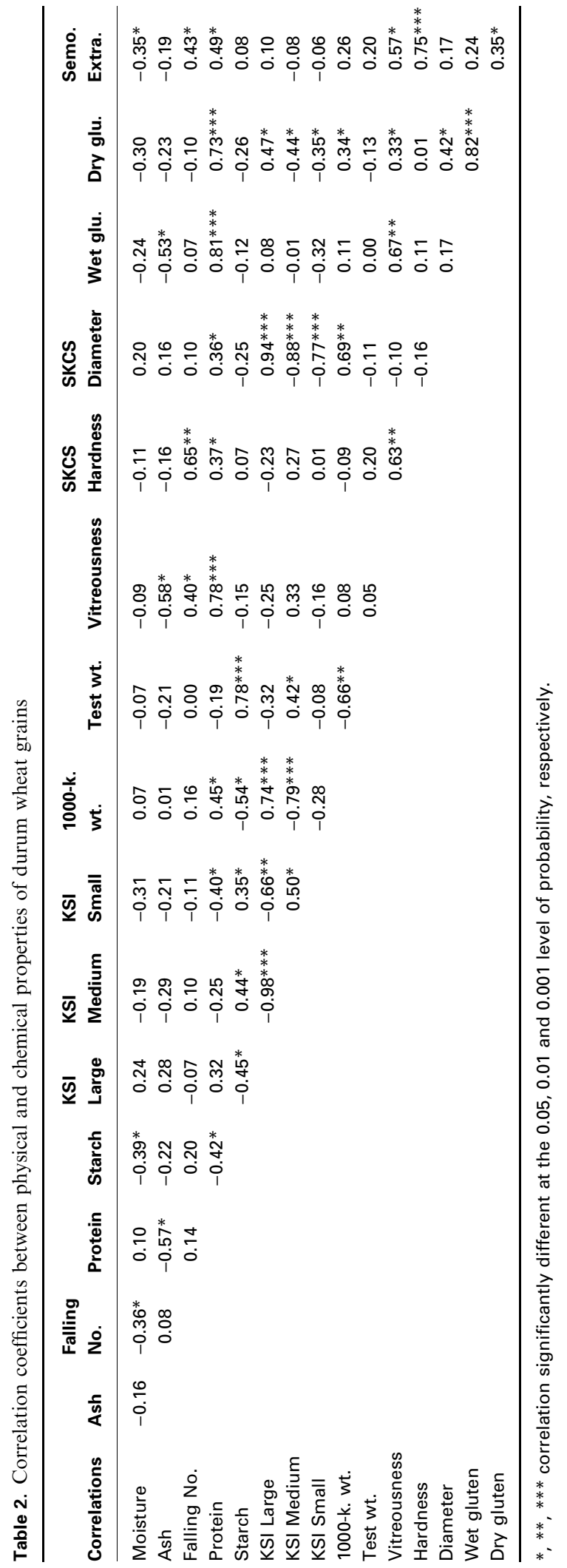

contrasting classes. The grades for this system are 1 (minimum of $78.2 \mathrm{~kg} \mathrm{hl}^{-1}$ ); 2 (minimum of $75.6 \mathrm{~kg} \mathrm{hl}^{-1}$ ); 3 (minimum of $73.0 \mathrm{~kg} \mathrm{hl}^{-1}$ ); 4 (minimum of $70.4 \mathrm{~kg} \mathrm{hl}^{-1}$ ); 5 (minimum of $66.5 \mathrm{~kg} \mathrm{~h}^{-1}$ ), so that two categories of grading based on vitreousness and test weight exist (Anon., 2003). These test weights would satisfy requirements for No. 1 grade for both the Canadian and US grading systems (CGC, 2001; Anon., 2003).

Hence, only two of the wheat genotypes studied would satisfy the Canadian grade No. 1 or the US Hard Amber Durum subclassification requirement (Douma18861 and Bohouth-7), while Sham-3 and Douma-26827 would be classified as Canadian grade No. 3, and Sham1, Sham-5, Bohouth-5, Douma-1105 and Douma-29019 being graded by the US subclassification of Durum as Amber Durum. All the durum wheat samples studied would also reach grade 1 standards according to the US grading system based on test weight.

\section{Chemical properties}

Chemical properties of the durum wheat genotypes are presented in Table 3. Moisture content ranged between 8.1 and 9.1. The low moisture contents reflect the desert environment in which the wheat was grown. Moisture content did not correlate strongly to any of the parameters evaluated, which probably reflects the narrow range in moisture content (Tables 2 and 3).

All of the tested genotypes showed falling number values above $400 \mathrm{~s}$, indicating sound grain with low $\alpha$-amylase activities (Matsuo et al., 1982a) (Table 3). Research conducted by Donnelly (1980) on durum wheat kernels indicated that falling number values less than $400 \mathrm{~s}$ were an indication of some degree of sprouting and may be related to poor quality attributes. A degree of variability was observed between our samples with Sham-1, Douma-1105 and Douma-26827 having falling number values below $500 \mathrm{~s}$ while the remaining genotypes had falling number values above $500 \mathrm{~s}$.

Some significant differences were observed in the ash content of the genotypes, with the studied genotypes ranging between $1.45 \%$ and $1.74 \%$ (on dry basis) (Table 3). Douma-29019 showing the lowest ash content of all genotypes and being significantly different to all genotypes excepting Douma-18861 and Douma-1105. This is likely to be due to the genetic similarity of the Douma samples compared with the Sham and Bohouth genotypes. The ash values for whole grain are at levels typically observed (Cubadda, 1988).

Protein content exhibited significant variations among the studied genotypes and ranged between $10.7 \%$ and $14.1 \%$ (on dry base) (Table 3), and generally showed lower values than durum wheat grown elsewhere (Autran \& Galterio, 1989; Carrillo et al., 1990; Ames 
Table 3 Chemical characteristics of grain from Syrian durum wheat genotypes

\begin{tabular}{llllll}
\hline Genotypes & Moisture \% & $\begin{array}{l}\text { Falling } \\
\text { No. Sec }\end{array}$ & $\begin{array}{l}\text { Ash } \\
(\mathbf{d b}) \%\end{array}$ & $\begin{array}{l}\text { Protein } \\
(\mathbf{d b}) \%\end{array}$ & $\begin{array}{l}\text { Starch } \\
(\mathbf{d b}) \%\end{array}$ \\
\hline Sham-1 & $8.5^{\mathrm{a}}$ & $433^{\mathrm{a}}$ & $1.65^{\mathrm{a}, \mathrm{b}}$ & $12.7^{\mathrm{a}, \mathrm{b}}$ & $64.4^{\mathrm{a}}$ \\
Sham-3 & $8.2^{\mathrm{a}}$ & $528^{\mathrm{b}}$ & $1.74^{\mathrm{a}}$ & $12.1^{\mathrm{a}}$ & $64.3^{\mathrm{a}}$ \\
Sham-5 & $8.3^{\mathrm{a}}$ & $502^{\mathrm{b}}$ & $1.70^{\mathrm{a}}$ & $12.9^{\mathrm{a}, \mathrm{b}}$ & $65.0^{\mathrm{a}, \mathrm{b}}$ \\
Bohouth-5 & $8.2^{\mathrm{a}}$ & $505^{\mathrm{b}}$ & $1.71^{\mathrm{a}}$ & $12.6^{\mathrm{a}, \mathrm{b}}$ & $66.2^{\mathrm{b}}$ \\
Bohouth-7 & $8.3^{\mathrm{a}}$ & $597^{\mathrm{c}}$ & $1.65^{\mathrm{a}, \mathrm{b}}$ & $12.7^{\mathrm{a}, \mathrm{b}}$ & $66.8^{\mathrm{b}}$ \\
Douma-1105 & $9.1^{\mathrm{a}}$ & $472^{\mathrm{d}}$ & $1.55^{\mathrm{a}, \mathrm{b}, \mathrm{c}}$ & $12.8^{\mathrm{a}, \mathrm{b}}$ & $64.4^{\mathrm{a}}$ \\
Douma-18861 & $8.1^{\mathrm{a}}$ & $524^{\mathrm{b}}$ & $1.47^{\mathrm{b}, \mathrm{c}}$ & $14.1^{\mathrm{c}}$ & $64.4^{\mathrm{a}}$ \\
Douma-26827 & $8.1^{\mathrm{a}}$ & $485^{\mathrm{d}}$ & $1.70^{\mathrm{a}}$ & $10.7^{\mathrm{d}}$ & $68.2^{\mathrm{c}}$ \\
Douma-29019 & $8.2^{\mathrm{a}}$ & $501^{\mathrm{b}}$ & $1.45^{\mathrm{c}}$ & $13.1^{\mathrm{b}}$ & $68.3^{\mathrm{c}}$ \\
\hline
\end{tabular}

${ }^{a}$ means values in the same column, followed by a different letter are significantly different $(p<0.05)$.

et al., 1999). The low protein contents of the genotypes examined may be an indication of the low nitrogen contents of the gypsiferous soils in which the crops were grown. Dry gluten contents of the kernels also varied between genotypes (results are not shown). Starch content of the samples ranged from $64.3 \%$ for Sham-3 to $68.3 \%$ for Douma-26827, and showed significant variations between genotypes (Table 3 ). A negative correlation between starch and protein $(r=-0.42)$ was observed (Table 2). This observation was to be expected as starch and protein levels (based as a \% of kernel weight) are intrinsically linked.

Protein content and test weight were not correlated (Table 2). Previous correlations by Tkachuk \& Kuzina (1979) and Matsuo \& Dexter (1980) have illustrated that low test weight is an indication of shrunken kernels and higher protein content. Durum kernels evaluated in this study were generally plump, with $>85 \%$ of the kernels classified as large (Table 1).

Positive correlations existed between protein content and the degree of vitreousness $(r=0.78)$ and kernel weight $(r=0.75)$ (Table 2). These results emphasise the role that protein has on kernel weight and the degree of vitreousness. Our previous research, on similar durum wheat genotypes, also demonstrated a correlation between protein content and vitreousness (El-Khayat et al., 2003). Protein content also had a positive correlation with semolina extraction $(r=0.49)$, which is probably related to the relationship between protein content and vitreousness. Dexter et al. (1989) reported that nonvitreous regions were low in protein.

Starch content of the kernel was negatively correlated with 1000-kernel weight $(r=-0.54)$, and was positively correlated with test weight $(r=0.78)$ (Table 2). It is of interest to note that starch content did not correlate with vitreousness in this particular study. However in our previous paper (El-Khayat et al., 2003) a clear relationship existed between high starch content and a decrease in kernel vitreousness.
The end-product utilisation of the durum wheat crop focuses on the semolina market, hence there exists the need to investigate the quality attributes needed to supply this market. It is recognised that high extraction rates for durum wheat semolina (rather than the smaller particle sized flour) is of importance to the miller (Troccoli et al., 2000), and that semolina yield is related to kernel hardness. Although researchers have linked factors such as test weight and 1000-kernel weight to semolina yield and hence indirectly to grain hardness (Marshall et al., 1986), our research showed that they are only parts of the answer when defining quality attributes. In this research all the genotypes had high test weight and kernel weight (Table 1). In this situation, kernel hardness and the degree of vitreousness and the falling number (measure of soundness and enzymic level of the kernel) became more important than small variations in test weight or kernel size. Both the degree of vitreousness and 1000-kernel weight are considered as primary factors in wheat grading (Dexter et al., 1987). Their effects on wheat milling have been widely investigated (Shuey, 1960; Matsuo \& Dexter, 1980; Matsuo et al., 1982b; Hook, 1984; Marshall et al., 1986; Dexter et al., 1987; Halverson \& Zeleny, 1988; Troccoli et al., 2000). Previous work has indicated that milling performance of the kernel was related to the size of the kernel, degree of vitreousness and overall hardness of the endosperm; hence, kernels with high protein content are generally assumed to yield more semolina than either starchy or piebald kernels (McDermott \& Pace, 1960; Matsuo, 1988; Troccoli \& Di Fonzo, 1999).

\section{Conclusions}

The Syrian durum wheat genotypes varied in kernel vitreousness, kernel hardness, kernel weight, kernel size, semolina extraction, falling number, protein content and starch content. All the Syrian durum wheat genotypes that were evaluated had hard to extremely hard, large, sound kernels which resulted in high test weights and kernel weights. However, all the genotypes tested had low protein content. Experimental line, Douma-18861, had greater vitreousness $(93.6 \%)$ and protein content $(14.1 \%)$ than any of the other genotypes $(50.4-85.7 \%$ and $10.7-13.1 \%$, respectively).

The quality attributes of durum wheat cultivars have often been defined in relation to bread wheat ( $T$. aestivum) samples, and the results of these experiments with Syrian durum wheat samples support these associations. Comparisons between the Canadian and US durum wheat grading systems illustrate that improvements in kernel quality are needed to enable the majority of the genotypes examined to reach the highest grade standards in relation to the degree of kernel vitreousness, 
whereas all samples were considered to be 1 grade in relation to test weight evaluations.

The results of our correlation analyses confirm the importance of three possible physico-chemical markers with regards to the milling quality attributes of durum wheat, namely the degree of kernel vitreousness, kernel hardness and kernel protein content. In our subsequent study, we aim to examine these parameters in relation to pasta quality and hence link the physico-chemical properties of the kernel to the end-product utilisation of the crop.

\section{References}

American Association of Cereal Chemists (2000). Approved Methods of the AACC, 10th edn. Methods 55-10, 44-15, 56-81B, 38-12, 08-01, 76-13. St Paul, MN: AACC.

Ames, N.P., Clarke, J.M., Marchylo, B.A., Dexter, J.E. \& Woods, S.M. (1999). Effect of environment and genotype on durum wheat gluten strength and pasta viscoelasticity. Cereal Chemistry, 76, $582-586$.

Anon. (2003) Crop Quality Report 2003. Pp. 23, 32. Washington, DC: US Wheat Associates.

Autran, J.C. \& Galterio, G. (1989). Association between electrophoretic composition of protein, quality characteristics, and agronomic attributes of durum wheat. II. Protein quality associations. Journal of Cereal Science, 9, 195-215.

Baldwin, P.M. (2001). Starch granule-associated proteins and polypeptides: a review. Starch, 53, 475-503.

Borrelli, G.M., Troccoli, A., Di Fanzo, N. \& Fares, C. (1999). Durum wheat lipoxygenase activity and other quality parameters that affect pasta color. Cereal Chemistry, 76, 335-340.

Brennan, C.S., Sulaiman, B.D., Schofield, J.D. \& Vaughan, J.G. (1993). The immunolocation of friabilin and its association with wheat endosperm texture. Aspects of Applied Biology Cereal Quality III, 36, 69-74.

Carrillo, J.M., Vasquez, M. \& Orellana, J. (1990). Relationship between gluten strength and glutenin proteins in durum wheat cultivars. Plant Breeding, 104, 325-333.

CGC (2001). Hard vitreous kernels. In: Official Grain Grading Guide. Winnipeg, MB: Industry Service, Canadian Grain Commission, Pp. 4-14-4-15, http://www.grainscanada.gc.ca

Chung, O.K., Ohm, J.B., Lookhart, G.L. \& Bruns, R.F. (2003). Quality characteristics of hard winter and spring wheats grown under an over-wintering condition. Journal of Cereal Science, 37, 91-99.

Cubadda, R. (1988). Evaluation of durum wheat, semolina and pasta in Europe. In: Durum Wheat: Chemistry and Technology (edited by G. Fabriani \& C. Lintus). Pp. 217-228. St Paul, MN: AACC.

Damidaux, R., Autran, J.C. \& Feillet, P. (1980). Gliadin electrophoregrams and measurements of gluten viscoelasticity in durum wheats. Cereal Foods World, 25, 754-756.

Delwiche, S.R. (1993). Measurement of single-kernel wheat hardness using Near-Infrared Transmittance. Transactions of the ASAE, 36, 1431-1437.

Dexter, J.E. \& Matsuo, R.R. (1977). Influence of protein content on some durum wheat quality parameters. Canadian Journal of Plant Science, 57, 717-727.

Dexter, J.E. \& Matsuo, R.R. (1980). Relationship between durum wheat proteins properties and pasta dough rheology and spaghetti cooking quality. Journal of Agriculture and Food Chemistry, 28, 899-902.

Dexter, E.J. \& Matsuo, R.R. (1981). Effect of starchy kernels, immaturity, and shrunken kernels on durum wheat quality. Cereal chemistry, 58, 395-400.
Dexter, J.E., Matsuo, R.R. \& Martin, D.G. (1987). The relationship on durum wheat test weight to milling performance and spaghetti quality. Cereal Foods World, 32, 772-777.

Dexter, J.E., Marchylo, B.A., MacGregor, A.W. \& Tkachuk, R. (1989). The structure and protein composition of vitreous, piebald and starchy durum wheat kernels. Journal of Cereal Science, $\mathbf{1 0}$, $19-32$.

Donnelly, B.J. (1980). Effect of sprout damage on durum wheat quality. Macaroni Journal, 62, 8-10.

Du Cros, D.L., Wrigley, C.W. \& Hare, R.A. (1982). Prediction of durum wheat quality from gliadin-protein composition. Australian Journal of Agriculture Research, 33, 429-442.

El-Khayat, H.G., Samaan, J. \& Brennan, C.S. (2003). Evaluation of vitreous and starchy Syrian durum (Triticum durum) wheat grains: the effect of amylose content on starch characteristics and flour pasting properties. Starch, 55, 358-365.

Greenwell, P. \& Schofield, J.D. (1986). A starch granule protein associated with endosperm softness in wheat. Cereal Chemistry, $\mathbf{6 3}$, 379-380.

Halverson, J. \& Zeleny, L. (1988). Criteria of wheat quality. In: Wheat: Chemistry and Technology (edited by Y. Pomeranz). Pp. 15-46. St Paul, MN: AACC.

Hook, S.C.W. (1984). Specific weight and wheat quality. Journal of the Science of Food and Agriculture, 35, 1136-1141.

Hoseney, R.C. (1987). Wheat hardness. Cereal Foods World, 32, $320-322$.

Igrejas, G., Gaborit, T., Oury, F., Chiron, H., Marion, D. \& Branlard, G. (2001). Genetic and environmental effects on puroindoline-a and puroindoline-b content and their relationship to technological properties in French bread wheats. Journal of Cereal Science, 34, $37-47$

Igrejas, G., Guedes-Pinto, H., Carnide, V., Clement, J. \& Branlard, G. (2002a). Genetical, biochemical and technological parameters associated with biscuit quality. II. Prediction using storage proteins and quality characteristics in a soft wheat population. Journal of Cereal Science, 36, 187-197.

Igrejas, G., Martinant, J.P., Bouguennec, A. et al. (2002b). Genetical, biochemical and technological parameters associated with biscuit quality. I. Prediction using grain hardness and water extractable arabinoxylans. Journal of Cereal Science, 36, 115-124.

Khatkar, B.S., Fido, R.J., Tatham, A.S. \& Schofield, J.D. (2002). Functional properties of wheat gliadins. I. Effects on mixing characteristics and bread making quality. Journal of Cereal Science, 35, 299-306.

Kim, W., Johnson, J.W., Graybosch, R.A. \& Gaines, C.S. (2003). Physicochemical properties and end-use quality of wheat starch as a function of waxy protein alleles. Journal of Cereal Science, 37, 195-204.

Kovacs, M.I.P., Poste, L.M., Butler, G. et al. (1997). Durum wheat quality: Comparison of chemical and rheological screening tests with sensory analysis. Journal of Cereal Science, 25, 65-75.

Mariani, B.M., D'Egidio, M.G. \& Novaro, P. (1995). Durum wheat quality evaluation: Influence of genotype and environment. Cereal Chemistry, 72, 194-197.

Marshall, D.R., Mares, D.J., Moss, H.J. \& Elliason, F.W. (1986). Effect of grain shape and size on milling yields in wheat. Experimental studies. Australian Journal of Agriculture Research, 37, 331-342.

Matsuo, R.R. (1988). Evaluation of durum wheat, semolina and pasta in Canada. In: Durum Wheat Chemistry and Technology (edited by G. Fabriani \& C. Lintas). Pp. 241-261. St Paul, MN: AACC.

Matsuo, R.R. \& Dexter, J.E. (1980). Relationship between some durum wheat characteristics and semolina milling properties. Canadian Journal of Plant Science, 60, 49-53.

Matsuo, R.R., Dexter, J.E. \& MacGregor, A.W. (1982a). Effect of sprout damage on durum wheat and spaghetti quality. Cereal Chemistry, 59, 468-472. 
Matsuo, R.R., Dexter, J.E., Kosmolak, F.G. \& Leisle, D. (1982b). Statistical evaluation of tests for assessing spaghetti-making quality of durum wheat. Cereal Chemistry, 59, 222.

McDermott, E.E. \& Pace, J. (1960). Comparison of the amino acid composition of protein in flour and endosperm from different types of wheat, with particular reference to variation in lysine content. Journal of the Science of Food and Agriculture, 11, 109-115.

Parish, J.A. \& Halse, N.J. (1968). Effects of light, temperature and the rate of desiccation on translucency in wheat grain. Australian Journal of Agriculture Research, 19, 365-372.

Pomeranz, Y. \& Williams, P.C. (1990). Wheat hardness: its genetic, structure and biochemical background, measurement and significance. In: Advances in Cereal Science and Technology (edited by Y. Pomeranz). Pp. 471-557. St Paul, MN: AACC.

Pomeranz, Y., Bolling, H. \& Zwingelberg, H. (1984). Wheat hardness and baking properties of wheat flour. Journal of Cereal Science, 2 , 137-143.

Sharma, R., Sissons, M.J., Rathjen, A.J. \& Jenner, C.F. (2002). The null-4A allele at the waxy locus in durum wheat affects pasta cooking quality. Journal of Cereal Science, 35, 287-297.

Shehadeh, A., Karneih, Y.\& Jubba, M. (1999). Durum wheat cultivation development in Syria. The Proceeding of Regional Workshop in Durum Wheat Improvment in the Dry Area of the VANA Regiona, Algezira.

Shuey, W.C. (1960). A wheat sizing technique for predicting flour milling yield. Cereal Science Today, 5, 71 .
Sissons, M.J., Osborne, B.G., Hare, R.A., Sissons, S.A. \& Jackson, R. (2000). Application of the single-kernel characterization system to durum wheat testing and quality prediction. Cereal Chemistry, $\mathbf{7 7}$ 4-10.

Stenvert, N.L. \& Kingswood, K. (1977). The influence of the physical structure of the protein matrix on wheat hardness. Journal of the Science of Food and Agriculture, 28, 11-19.

Symes, K. (1961). Classification of Australian wheat varieties based on the granularity of their wholemeal. Australian Journal of Experimental Agriculture and Animal husbandry, 1, 18-23.

Taha, S.A. \& Sagi, F. (1987). Relationship between chemical composition of durum wheat semolina and macaroni quality. II Ash, carotenoid pigments, and oxidative enzymes. Cereal Research Communication, 15, 123-129.

Tkachuk, R. \& Kuzina, F.D. (1979). Wheat: relations between some physical and chemical properties. Canadian Journal of Plant Science, 59, 15-20.

Troccoli, A. \& Di Fonzo, N. (1999). Relationship between kernel size features and test weight in Triticum durum. Cereal Chemistry, 76, 45-49.

Troccoli, A., Borreli, G.M., De Vita, P., Fares, C. \& Di Fonzo, N. (2000). Durum wheat quality: a multidisciplinary concept. Journal of Cereal Science, 32, 99-113.

Yamazaki, W.T. \& Donelson, J.R. (1983). Kernel hardness of some US wheats. Cereal Chemistry, 60, 344-350. 